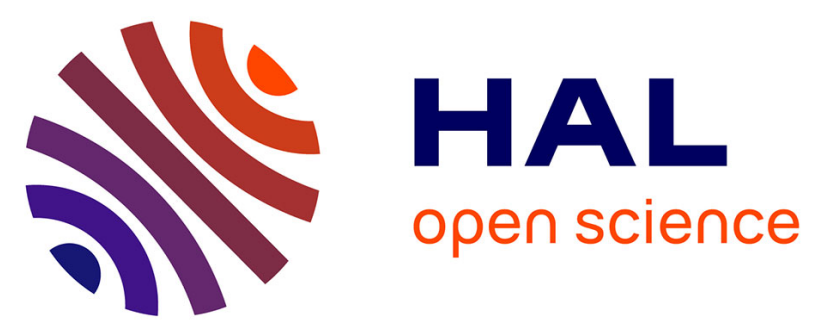

\title{
Direct effect of dehydroepiandrosterone sulphate (DHEAS) on PC-12 cell differentiation processes
}

Christian G. Ziegler, Heike Langbein, Alexander W. Krug, Barbara Ludwig, Graeme Eisenhofer, Monika Ehrhart-Bornstein, Stefan R. Bornstein

\section{To cite this version:}

Christian G. Ziegler, Heike Langbein, Alexander W. Krug, Barbara Ludwig, Graeme Eisenhofer, et al. Direct effect of dehydroepiandrosterone sulphate (DHEAS) on PC-12 cell differentiation processes. Molecular and Cellular Endocrinology, 2011, 336 (1-2), pp.149. 10.1016/j.mce.2010.12.031 . hal00675794

\section{HAL Id: hal-00675794 \\ https://hal.science/hal-00675794}

Submitted on 2 Mar 2012

HAL is a multi-disciplinary open access archive for the deposit and dissemination of scientific research documents, whether they are published or not. The documents may come from teaching and research institutions in France or abroad, or from public or private research centers.
L'archive ouverte pluridisciplinaire $\mathbf{H A L}$, est destinée au dépôt et à la diffusion de documents scientifiques de niveau recherche, publiés ou non, émanant des établissements d'enseignement et de recherche français ou étrangers, des laboratoires publics ou privés. 


\section{Accepted Manuscript}

Title: Direct effect of dehydroepiandrosterone sulphate (DHEAS) on PC-12 cell differentiation processes

Authors: Christian G. Ziegler, Heike Langbein, Alexander W. Krug, Barbara Ludwig, Graeme Eisenhofer, Monika Ehrhart-Bornstein, Stefan R. Bornstein

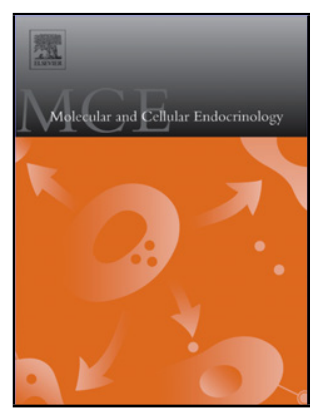

PII: S0303-7207(10)00624-6

DOI: doi:10.1016/j.mce.2010.12.031

Reference: MCE 7736

To appear in: $\quad$ Molecular and Cellular Endocrinology

Received date: $\quad 24-8-2010$

Revised date: $\quad 3-12-2010$

Accepted date: $\quad$ 21-12-2010

Please cite this article as: Ziegler, C.G., Langbein, H., Krug, A.W., Ludwig, B., Eisenhofer, G., Ehrhart-Bornstein, M., Bornstein, S.R., Direct effect of dehydroepiandrosterone sulphate (DHEAS) on PC-12 cell differentiation processes, Molecular and Cellular Endocrinology (2010), doi:10.1016/j.mce.2010.12.031

This is a PDF file of an unedited manuscript that has been accepted for publication. As a service to our customers we are providing this early version of the manuscript. The manuscript will undergo copyediting, typesetting, and review of the resulting proof before it is published in its final form. Please note that during the production process errors may be discovered which could affect the content, and all legal disclaimers that apply to the journal pertain. 


\section{Direct effect of dehydroepiandrosterone sulphate (DHEAS) on PC-12 cell differentiation processes}

Christian G. Ziegler*, Heike Langbein, Alexander W. Krug, Barbara Ludwig, Graeme Eisenhofer, Monika Ehrhart-Bornstein and Stefan R. Bornstein, Carl Gustav Carus University Hospital, Medical Clinic III, University of Dresden, Germany

* Corresponding author: Dr. rer. nat. Christian G. Ziegler

Carl Gustav Carus University Hospital, Medical Clinic III University of Dresden,

Fetscherstr. 74

01307 Dresden, Germany;

Telephone: +493514586615 / Fax: +49351/4586336;

E-Mail: Christian.Ziegler@uniklinikum-dresden.de

Short title: Direct effects of DHEAS on PC12-cells

Reprint requests to corresponding author

Disclosure statement: The authors of this manuscript have nothing to disclose 


\begin{abstract}
Dehydroepiandrosterone sulphate (DHEAS) is classically seen as an inactive reservoir for the production of dehydroepiandrosterone (DHEA). Steroid sulfatase (STS) is the enzyme that catalyzes the hydrolysis of DHEAS to DHEA, which can then be further metabolized to other steroid hormones. Recent studies, however, indicate that DHEAS can mediate biological effects without being converted to DHEA.

This study aims to evaluate whether DHEAS itself influences the differentiation of PC-12 cells or if its desulfation to DHEA is required. DHEA and DHEAS both influence the differentiation of chromaffin PC-12 cells. Blocking steroid sulfatase activity and thereby the conversion of DHEAS to DHEA by the enzyme blocker estrone sulfamate (EMATE) showed that the effect of DHEAS is independent of its conversion to DHEA. DHEAS, similar to DHEA, reduced nerve growth factor (NFG)-induced neurite outgrowth of PC-12 cells and the expression of synaptosomal-associated membrane protein of $25 \mathrm{kDa}$ (SNAP-25), increased the expression of chromogranin A (CGA) and significantly increased dopamine release of PC-12 cells. In addition, DHEAS, DHEA and membrane impermeable DHEA-BSA all significantly reduced NGF-induced MAPK ERK1/2 signaling after 5 minutes.

In summary, this study provides evidence that DHEAS, independent of its conversion to DHEA, directs PC-12 cells' differentiation to a neuroendocrine direction. Furthermore, employing membrane-impermeable DHEA-BSA indicates the involvement of plasmamembrane bound receptors.
\end{abstract}

Key words: Dehydroepiandrosterone-sulfate (DHEAS), steroid sulfatase, estrone sulfamate (EMATE) 


\section{Introduction}

Dehydroepiandrosterone (DHEA) and its sulfate ester DHEA-sulfate (DHEAS) are the major androgens produced by the human adrenal cortex. More than 99\% (3.5 to $20 \mathrm{mg} / \mathrm{daily}$ ) of DHEA is sulfated to DHEAS prior to secretion (Burger, 2002). The normal range of DHEA plasma levels in humans is $7-31 \mathrm{~nm}$. DHEAS ranges from 1.3 to $6.8 \mu \mathrm{m}$ (Chen et al., 2005) representing the primary circulating form of DHEA with concentrations more than 100 -fold higher than any other steroid hormone. Steroid sulfatase (STS) is the enzyme that catalyzes the hydrolysis of steroid sulfates to their unconjugated, biologically active forms (Stanway et al., 2007). In the periphery, STS converts DHEAS to DHEA, which can then be further metabolized to other steroid hormones; conversely, DHEA can be inactivated via sulfonation to DHEAS by cytosolic hydroxysteroid sulfotransferase SA1 (SULT2A1) (Hammer et al., 2005). Due to its rapid metabolic clearance rate, DHEA has a rather short half-life of 1-3 hours, while the half-life of DHEAS is 10-20 hours (Rosenfeld et al., 1975).

DHEA and DHEAS are widely distributed throughout the body and DHEAS has long been seen merely as a circulating storage pool for DHEA regeneration (Chen et al., 2005). Numerous recent studies, however, have demonstrated that DHEAS indeed can have a direct impact on various cell systems. DHEAS can be synthesized de novo in the CNS and in brain glial cells from cholesterol or from steroid precursors through mechanisms partly independent of peripheral steroidogenic endocrine glands, gonads or adrenals and was found to directly increase the length of neurites (Compagnone and Mellon, 1998). Among other major biological actions of DHEAS are those associated with neuroprotection, neuronal survival, apoptosis, catecholamine synthesis and secretion, as well as antioxidant, antiinflammatory and anti-glucocorticoid effects (for review (Maninger et al., 2009). Furthermore, DHEAS was found to inhibit vascular smooth muscle cell (VSMC) proliferation (li et al., 2009) and to directly increase superoxide formation in neutrophils (Radford et al., 2010). Our own recent data show that DHEA and DHEAS differentially modulate growth factor-induced proliferation of bovine adrenomedullary chromaffin cells in an age-dependent manner. While DHEA reduced the proliferation of adrenal cells from young and adult animals, DHEAS exclusively increased the proliferation in adult-cell cultures. These effects were not mediated by androgen or estrogen receptors (Sicard et al., 2007). Our studies on PC-12 cells further demonstrated that DHEA (Ziegler et al., 2008) and DHEAS (Krug et al., 2009) promote a neuroendocrine phenotype of these cells.

The present study aims to clarify whether the effects of DHEAS on PC-12 cell differentiation are indeed mediated directly by DHEAS or are exerted by DHEA after 
conversion by STS. By blocking this enzyme we were able to pin down direct effects of DHEAS on chromaffin PC12 cells.

\section{Materials and methods}

\subsection{Cell culture}

Rat PC12 cells were sustained in Kaighn's modified Ham's F-12 medium (ATCC, Manassas, USA) with $2 \mathrm{mmol} / \mathrm{l}$ l-glutamine and $1500 \mathrm{mg} / \mathrm{l}$ sodium bicarbonate supplemented with $15 \%$ horse serum, $2.5 \%$ fetal calf serum (FCS) and $20 \mathrm{U} / \mathrm{ml}$ penicillin-streptomycin (Gibco, Gaithersburg MD, USA) in a humidified $5 \% \mathrm{CO}_{2} / 95 \% \mathrm{O}_{2}$ atmosphere at $37^{\circ} \mathrm{C}$. The culture medium was changed every other day. Cells were grown in this culture medium for $72 \mathrm{~h}$, and left in serum-free medium overnight prior to the experiments. DHEA and DHEABSA were dissolved in ethanol, DHEAS and NGF were dissolved in DMSO and $10 \mathrm{mmol} / \mathrm{l}$ sodium acetate $(\mathrm{pH} 5)$, respectively. The final volume of ethanol or DMSO in each well, including controls, was $0.01 \%$ for all assays performed. The solvents had no effect in control experiments.

\subsection{RNA isolation and RT-PCR}

RNA was isolated using the Quiagen RNeasy Plus kit, according to the manufacturer's instructions (Quiagen, Germany). This kit includes DNA binding columns to exclude genomic DNA. Furthermore, for avoidance of genomic DNA amplification we used the exon-spanning primers for STS detection.

For reverse transcriptase (RT)-PCR, $500 \mathrm{ng}$ RNA from each sample was reverse transcribed into cDNA by Moloney murine leukemia (MML) virus reverse transcriptase using random primers (Promega) in a final volume of $20 \mu \mathrm{l}$. One $\mu \mathrm{l}$ of cDNA was amplified in a 10 $\mu$ solution containing $1.5 \mathrm{mM} \mathrm{MgCl}_{2}, 1 \times P C R$ buffer (Invitrogen, CA, USA), $0.25 \mathrm{mM}$ of each deoxynucleotide (Promega), 1 unit of Taq DNA polymerase (Invitrogen, CA, USA) and 5 pmol of each of the different primers. Samples were denatured for $5 \mathrm{~min}$ at $94^{\circ} \mathrm{C}$, then subjected to $15 \mathrm{~s} 94^{\circ} \mathrm{C}, 15 \mathrm{~s} 65^{\circ} \mathrm{C}, 15 \mathrm{~s} 72^{\circ} \mathrm{C}$ and $\min 72^{\circ} \mathrm{C}$ for 40 cycles altogether. After agarose gel electrophoresis and ethidium bromide staining, bands were visualized under UV light.

Exon-spanning primer were found through data base search and checked for right length and position using BLAST (basic local alignment search tool). Primer sequences (5'-3'): ACTCCAACTCAGCTACAACCTGGTG and CACAGAGAAAGTTGAGCTGGGAGAG.

\subsection{Neurite outgrowth}

Single cell suspensions were plated in $200 \mathrm{~mm}^{2}$ wells at a density of $2 \times 10^{4}$ cells per well in serum-free culture medium, then treated with NGF $(20 \mathrm{ng} / \mathrm{ml})$ and DHEAS or DHEA $\left(10^{-6}\right.$ 
$\mathrm{mol} / \mathrm{l})$, alone and in combination as well as w/wo EMATE $\left(10^{-6} \mathrm{~mol} / \mathrm{l}\right)$. After $24 \mathrm{~h}$ incubation, the percentage of cells showing neurite outgrowth was determined by light microscopy. Cells with one or more neurites whose lengths were at least twice the diameter of the cell body were scored as positive. Neurite outgrowth was determined from at least three different regions of interest ( $\mathrm{ROI}$ ) in three independent experiments (Kim et al., 2004; Xiao et al., 2002; Ziegler et al., 2008).

\subsection{High-performance liquid chromatography (HPLC)}

Dopamine concentrations in culture medium were determined as previously described (Ziegler et al., 2008). Briefly, catecholamines were extracted by solid-phase extraction after $24 \mathrm{~h}$ stimulation of cells with NGF $(20 \mathrm{ng} / \mathrm{ml})$ and DHEA as well as DHEAS $\left(10^{-6} \mathrm{~mol} / \mathrm{l}\right)$, alone and in combination as well as w/wo EMATE $\left(10^{-6} \mathrm{~mol} / \mathrm{l}\right)$. The cell medium samples were processed according to the sample preparation protocol for urine (Chromsystems, Munich, Germany). $6 \mathrm{ml}$ neutralization buffer and $100 \mu \mathrm{l}$ internal standard (3,4-dihydroxybenzylamine) were added to $3 \mathrm{ml}$ cell medium. This mixture was run on a sample clean-up column by vacuum. The eluate was discarded. Subsequently, the solid-phase extraction column was washed twice with pure water $(10 \mathrm{ml})$ and eluted with $6 \mathrm{ml}$ elution buffer by vacuum. Finally, the eluate was collected and acidified with $180 \mu \mathrm{l} 5 \mathrm{~N} \mathrm{HCl}$. An aliquot of the purified eluate was applied to a HPLC reverse-phase column, and dopamine concentrations were measured using an electrochemical detector (Bio-Rad, Munich, Germany). Dopamine measurements were quantified in correlation to the added internal standard.

\subsection{Western blot analysis}

Western blot analysis was performed as previously described (Krug et al., 2003). PC-12 cells were washed twice in ice-cold phosphate-buffered saline (PBS) and lysed in ice-cold Cell Lytic Mammalian Cell Lysis/Extraction reagent (Sigma) containing 1\% protease inhibitor cocktail (Sigma). Cell lysates were matched for protein content. Protein concentrations were determined by BCA assay (PIERCE, Rockford, USA). Proteins were separated by sodium dodecyl sulfate polyacrylamide gel electrophoresis (SDS-PAGE) and transferred to nitrocellulose membrane. After blocking, membranes were immunostained using the following antibodies: rabbit anti-phospho-ERK1/2 (1:1000, Cell Signaling, Danvers, USA), rabbit anti-SNAP25 (1:5000, Sigma-Aldrich, Steinheim, Germany), goat anti-chromogranin A (CgA) (1:500, Santa Cruz, Heidelberg, Germany) and rabbit anti- $\beta$-actin (1:500, Cell Signaling, Danvers, USA). The bands were visualized using peroxide solution and luminol solution (PIERCE, Rockford, USA). Chemoluminescence signals were read with the GeneGnome Chemoluminescence detector (Syngene, Frederick, USA). As a loading control we used the house-keeping gene B-actin 


\subsection{Quantification of ERK1/2 phosphorylation by ELISA}

We performed in situ cell-based ELISA as described previously, in a slightly modified way (Krug et al., 2009). Cells were seeded in 96-well plates at a concentration of 20,000 cells per $0.32 \mathrm{~cm}^{2}$ and after reaching approximately $80 \%$ confluence, were serum-starved for $24 \mathrm{~h}$. Subsequently, cells were equilibrated in $1 \times \mathrm{HEPES}-$ Ringer solution $(130.0 \mathrm{mmol} / \mathrm{I} \mathrm{NaCl}$, $5.4 \mathrm{mmol} / \mathrm{K} \mathrm{KCl}, 1.0 \mathrm{mmol} / / \mathrm{CaCl}_{2}, 1.0 \mathrm{MgCl}_{2}, 1.0 \mathrm{mmol} / / \mathrm{NaH}_{2} \mathrm{PO}_{4}, 10 \mathrm{mmol} / \mathrm{l} \mathrm{HEPES}$, and $5 \mathrm{mmol} / \mathrm{lg}$ glucose; $\mathrm{pH} \mathrm{7.4)}$ at $37^{\circ} \mathrm{C}$ for $30 \mathrm{~min}$, and then stimulated in the same buffer w/wo the hormones and growth factors of interest. After fixation of cells with $8 \%$ formaldehyde in PBS, endogenous peroxidases were quenched with freshly prepared $1 \% \mathrm{H}_{2} \mathrm{O}_{2}$ and $0.1 \%$ azide. Cells were washed again three times in the same buffer, blocked by $5 \%$ FCS in PBS/Triton for $1 \mathrm{~h}$ and, finally, incubated overnight with the primary antibody (pERK, Cell Signaling, $1: 1000$ ) in PBS/Triton containing $5 \%$ bovine serum albumin at $4{ }^{\circ} \mathrm{C}$. The next day, cells were washed three times with PBS/Triton and incubated with the secondary antibody (anti-rabbit HRP-linked lgG, Cell Signaling, 1:3000) in PBS/Triton containing 5\% bovine serum albumin for $1 \mathrm{~h}$ at room temperature. After one washing step, chemoluminescence signals were read using a Mithras multi-well reader (Berthold Technologies, Bad Wildberg, Germany). After two washing steps, air-dried wells were stained with $100 \mu$ of crystal violet solution ( $0.25 \%$ in PBS) for 30 min at room temperature. Following three PBS washing steps, $100 \mu \mathrm{l}$ of $1 \%$ SDS solution was added and the plate was incubated on a shaker for $1 \mathrm{~h}$ at room temperature. Finally, absorbance was measured at $595 \mathrm{~nm}$. Chemoluminescence signals were normalized to the protein content in each well as determined by crystal violet staining. This step allows normalizing ERK1/2 phosphorylation to total protein content per well.

\subsection{Statistical analysis}

In all experiments, statistical differences between experimental groups relative to appropriate controls were determined by analysis of variance (ANOVA). Data are presented as means \pm S.E.M. Significance of differences was tested by analysis of variance with Bonferroni's as a secondary test. Differences were considered significant at values of $p<0.05$. Cells from at least two different passages were used for each experimental series; $n$ represents the number of cells or tissue culture dishes investigated.

\section{Results}

The prerequisite for the conversion of DHEAS to DHEA is the expression of the enzyme steroid sulfatase which catalyzes the conversion of DHEAS to DHEA. RT-PCR analysis revealed the expression of STS in PC-12 cells (Fig. 1). 
To indentify possible direct effects of DHEAS, intracellular STS activity was blocked by addition of the enzyme blocker estrone sulfamate (EMATE). The effects of both DHEA and DHEAS were evaluated in the presence and absence of EMATE. We focused on various neuronal and neuroendocrine differentiation parameters in accordance with our previous studies on chromaffin PC-12 cells (Krug et al., 2009; Ziegler et al., 2008; Ziegler et al., 2006).

Incubation of PC-12 cells with NGF lead to neurite outgrowth of the cells as early as $24 \mathrm{~h}$ after stimulation (Ziegler et al., 2008). Both androgens $\left(10^{-6} \mathrm{~mol} / \mathrm{l}\right)$ were found to reduce this NGF (20 ng/ml)-induced neurite outgrowth by $72 \%$ for DHEA and $58 \%$ for DHEAS after $24 \mathrm{~h}$. Addition of EMATE and thus inhibiting the conversion of DHEAS to DHEA had no significant effect on DHEAS-induced reduction of neurite outgrowth. DHEA, DHEAS and EMATE alone did not affect neurite outgrowth (Fig. 2). Furthermore, lower concentrations of DHEA $\left(10^{-7}-10^{-}\right.$ $10 \mathrm{~mol} / \mathrm{l})$ or DHEA-S $\left(10^{-7}-10^{-9} \mathrm{~mol} / \mathrm{l}\right)$ were also checked and not found to induce neurite outgrowth in our experimental setting. This is in accordance with our previous publications (Krug et al., 2009; Ziegler et al., 2008).

Associated with NGF-induced neurite outgrowth of PC-12 cells is the expression of neuronal marker proteins, such as synaptosome-associated protein of 25kDa (SNAP-25) (Krug et al., 2009). DHEAS and DHEA $\left(10^{-6} \mathrm{~mol} / \mathrm{l}\right)$ both reduced NGF $(20 \mathrm{ng} / \mathrm{ml})$-induced expression of SNAP-25 after $24 \mathrm{~h}$ by $14 \%$ for DHEA and $18 \%$ for DHEAS respectively, as demonstrated by Western blotting. The conversion of DHEAS to DHEA was blocked by EMATE. DHEA, DHEAS and EMATE alone $\left(10^{-6} \mathrm{~mol} / \mathrm{l}\right)$ did not influence SNAP-25 expression (Fig. 3). DHEA and DHEAS at concentrations of $10^{-6} \mathrm{~mol} / \mathrm{l}$ significantly reduced NGF-induced expression of SNAP-25. Lower concentrations of the androgens were also tested and not as effective (Krug et al., 2009; Ziegler et al., 2008).

Catecholamine secretion and the expression of neuroendocrine marker proteins, such as chromogranin A (CGA) are features of the neuroendocrine differentiation processes of PC-12 cells. Concordantly with the reduction of neuronal cell differentiation parameters, both androgens $\left(10^{-6} \mathrm{~mol} / \mathrm{l}\right)$ directly increased the expression of the neuroendocrine marker protein CGA after $24 \mathrm{~h}$ by $115 \%$ for DHEA and $120 \%$ for DHEAS, as demonstrated by Western blotting. Co-incubation with NGF $(20 \mathrm{ng} / \mathrm{ml})$ reduced the androgens' effects; NGF alone did not influence CGA expression. Blocking the conversion of DHEAS to DHEA by EMATE had no effect on the DHEAS-induced increase of CGA concentrations within the cells (Fig. 4). The most effective concentration was $10^{-6} \mathrm{~mol} / \mathrm{l}$ for DHEA, DHEAS also at $10^{-7}$ mol/l was significantly influencing CGA expression (Krug et al., 2009; Ziegler et al., 2008). 
Furthermore, DHEA and DHEAS $\left(10^{-6} \mathrm{~mol} / \mathrm{l}\right)$ similarly and significantly increased dopamine release from NGF (20 ng/ml)-induced PC-12 cells by $370 \%$ for DHEA and $320 \%$ for DHEAS, after 24h; no significant effect was observed when these hormones were given alone. The enzyme blocker $\left(10^{-6} \mathrm{~mol} / \mathrm{l}\right)$ alone had no effect on dopamine secretion (Fig. 5). The most effective concentration was $10^{-6} \mathrm{~mol} / \mathrm{l}$ for DHEA; DHEAS also at $10^{-7} \mathrm{~mol} / \mathrm{l}$ was significantly influencing NGF (20 ng/ml)-induced dopamine release (Krug et al., 2009; Ziegler et al., 2008).

Our results provide evidence for direct effects of DHEAS on PC-12 cell differentiation processes independent of its conversion to DHEA as demonstrated by blocking the conversion with EMATE. In accordance to our previous studies, both androgens seem to shift PC-12 cells towards a more neuroendocrine phenotype, as revealed by reduced neurite outgrowth and reduced neuronal marker protein expression. Furthermore, DHEAS and DHEA significantly influenced CGA expression and catecholamine secretion.

Recently, Charalampopoulos and co-workers provided a mechanism for DHEA action, concluding that this androgen might mediate its action via a fast non-genomic effect including plasma-membrane binding as a first step of action (Charalampopoulos et al., 2006). In accordance, our data reveal that DHEA as well as the membrane impermeable DHEA-BSA exerts an identical reduction of NGF-induced ERK1/2 phosphorylation. The involvement of a membrane component is also indicated by the rapid onset of DHEA and DHEAS effects within 5 min (Fig. 6).

\section{Discussion}

This study provides evidence of a direct effect of DHEAS on chromaffin cell differentiation processes independent of a conversion of DHEAS to DHEA. Together with our recent work where we showed that these androgens regulate proliferation of primary chromaffin cells (Sicard et al., 2007), differentiation of chromaffin progenitors (Chung et al., unpublished data) and of chromaffin PC12 cells (Ziegler et al., 2008), these data suggest significant direct effects of both androgens on adrenal biology in different stages of adrenal development.

Classically, DHEAS, which circulates in micromolar amounts in the human body, is assumed to have no independent biological function other than an inactive storage pool for DHEA (Arlt and Stewart, 2005). However, different lines of evidence recently suggested direct DHEAS effects independent of its conversion to DHEA. Thus, the two androgens in vitro differentially modulated growth factor-induced proliferation of bovine adrenomedullary chromaffin cells (Sicard et al., 2006) in an age-dependent manner (Sicard et al., 2007). While 
DHEA reduced the proliferation of adrenal cells from young and adult cattle, DHEAS exclusively increased the proliferation in adult cell cultures. These effects were not mediated by androgen or estrogen receptors (Sicard et al., 2007). Furthermore, while DHEAS and DHEA stimulated catecholamine secretion from PC12 cells (Charalampopoulos et al., 2005; Krug et al., 2009; Ziegler et al., 2008) only DHEAS but not DHEA stimulated catecholamine synthesis (Charalampopoulos et al., 2005). DHEA and DHEAS also had different effects on the growth of embryonic rodent cortical neuronal neurite growth (Compagnone and Mellon, 1998). In addition, it was recently shown that DHEAS, but not DHEA, increases superoxide generation in primed human neutrophils, thereby impacting on a key bactericidal mechanism (Radford et al., 2010). These studies indicate that DHEAS not solely represents a circulating storage pool for DHEA regeneration but indeed mediates direct effects.

By blocking the DHEAS converting enzyme steroid sulfatase, we provide evidence for direct effects of DHEAS on chromaffin cell differentiation processes, independent of its conversion to DHEA. Thus, DHEAS directed PC12 cells to a more endocrine differentiation by inhibiting NGF-induced PC-12 cells neurite outgrowth, influencing neuronal and neuroendocrine marker protein expression as well as the MAPK ERK1/2 signaling pathway. These data adds to recent studies demonstrating important direct effects of DHEAS on various biological parameters (for review (Maninger et al., 2009).

PC-12 cells are a widely used model to study adrenal catecholamine metabolism, chromaffin cell proliferation, and differentiation processes as well as the underlying signaling events (Vaudry et al., 2002). PC-12 cells also harbor features of early chromaffin progenitor cells which can differentiate into either chromaffin cells or sympathetic neurons under the influence of different growth factors and adrenocortical steroid hormones (Beaujean et al., 2003; Eaton and Duplan, 2004). They are thus a useful model for studying adrenal chromaffin cell development.

In the adrenal gland, adrenocortical and adrenomedullary systems are intimately linked both anatomically and functionally (Ehrhart-Bornstein et al., 1998), suggesting a close bidirectional crosstalk. Human adrenal chromaffin cells are in direct contact with the inner androgen producing zone, the zona reticularis, and are thus exposed to high concentrations of adrenal androgens, predominantly DHEA and DHEAS. This is especially relevant during fetal development where DHEA and DHEAS are the major products of the adrenal premordium when the neural crest derived sympathoadrenal progenitor cells invade these adrenal anlagen (Ehrhart-Bornstein et al., 1997; Mesiano and Jaffe, 1997). There they 
acquire the features of neuroendocrine catecholamine-producing cells, suggesting a direct influence of DHEA and DHEAS in the development and maintenance of the adrenal medulla.

Our previous work on PC-12 cells (Ziegler et al., 2008; Ziegler et al., 2006) demonstrated that DHEA and DHEAS promote a neuroendocrine differentiation while reducing neuronal cell parameters, possibly via ERK1/2 MAPK signaling; ERK1/2 MAPK pathway is involved in PC-12 cell proliferation and differentiation processes. NGF rapidly induces this pathway, an effect significantly reduced by DHEA (Ziegler et al., 2008) and DHEAS (Krug et al., 2009). Since DHEA and DHEAS are not cytotoxic for PC-12 cells (data not shown), this indicates a shift of PC-12 cells towards differentiation (Ziegler et al., 2008). Blocking the conversion of DHEAS to DHEA now proves that these effects were indeed mediated by DHEAS directly.

A specific receptor for DHEA and DHEAS has not been identified to date. In our previous studies we were able to exclude the action via classical steroid receptors since neither the estrogen receptor antagonist $\mathrm{ICI} 182,780$ nor the androgen receptor antagonist flutamide inhibited DHEA/DHEAS effects (Sicard et al., 2007; Ziegler et al., 2008). Recent studies have indicated that plasma membrane-associated receptors can mediate fast steroid effects, therefore being involved in important physiological and pathological processes (Charalampopoulos et al., 2006; Liu and Dillon, 2002; Liu et al., 2003). In accordance with these studies, the inhibition of NGF-induced differentiation process also by a membrane impermeable DHEA-BSA complex provides further evidence for the involvement of plasmamembrane bound receptors in DHEA and possibly also DHEAS effects. Furthermore, the rapid onset of DHEA and DHEAS effects within $5 \mathrm{~min}$ supports the hypothesis that a membrane component is implicated in the action of these steroids. In a recent study, a photoreactive, biotinylated DHEA analogue was successfully synthesized; this compound might help to further identify plasma membrane DHEA binding sites and eventually also to purify a possible receptor (Liu et al., 2010). In contrast to the lipophilic DHEA, DHEAS, due to its hydrophilic nature does not enter the cell (Hammer et al., 2005) indicating a membrane bound receptor for this steroid. The suggested regulation of PC-12 differentiation is summarized in Figure 7.

Our combined recent data reveals decisive roles of both DHEA and DHEAS in the differentiation and function of adrenal medullary chromaffin cells. Both androgens seem to influence the fate of the neighboring adrenomedullary chromaffin cells during different developmental steps. 


\section{Acknowledgements}

We thank Dr. Peter Lattke for catecholamine HPLC analysis, Linda Gebauer for expert technical assistance, and Kathleen Eisenhofer for help in the preparation of the manuscript. This work was supported by the Deutsche Forschungsgemeinschaft Grant SFB 655 "From Cells to Tissues" (to M.E.B. and S.R.B.) and MedDrive, University of Dresden (to C.G.Z).

\section{References}

Arlt, W. and Stewart, P.M., 2005. Adrenal corticosteroid biosynthesis, metabolism, and action. Endocrinol Metab Clin North Am 34, 293-313.

Beaujean, D., Rosenbaum, C., Muller, H.W., Willemsen, J.J., Lenders, J. and Bornstein, S.R., 2003. Combinatorial code of growth factors and neuropeptides define neuroendocrine differentiation in PC12 cells. Exp Neurol 184, 348-358.

Burger, H.G., 2002. Androgen production in women. Fertil Steril 77 3-5.

Charalampopoulos, I., Alexaki, V.I., Lazaridis, I., Dermitzaki, E., Avlonitis, N., Tsatsanis, C., Calogeropoulou, T., Margioris, A.N., Castanas, E. and Gravanis, A., 2006. G protein-associated, specific membrane binding sites mediate the neuroprotective effect of dehydroepiandrosterone. FASEB J 20, 577-579.

Charalampopoulos, I., Dermitzaki, E., Vardouli, L., Tsatsanis, C., Stournaras, C., Margioris, A.N. and Gravanis, A., 2005. Dehydroepiandrosterone Sulfate and Allopregnanolone Directly Stimulate Catecholamine Production Via Induction of Tyrosine Hydroxylase and Secretion by Affecting Actin Polymerization. Endocrinology 146, 3309-3318.

Chen, F., Knecht, K., Birzin, E., Fisher, J., Wilkinson, H., Mojena, M., Moreno, C.T., Schmidt, A., Harada, S., Freedman, L.P. and Reszka, A.A., 2005. Direct agonist/antagonist functions of dehydroepiandrosterone. Endocrinology 146, 45684576.

Compagnone, N.A. and Mellon, S.H., 1998. Dehydroepiandrosterone: a potential signalling molecule for neocortical organization during development. Proc Natl Acad Sci U S A 95, 4678-4683.

Eaton, M.J. and Duplan, H., 2004. Useful cell lines derived from the adrenal medulla. Mol Cell Endocrinol 228, 39-52.

Ehrhart-Bornstein, M., Breidert, M., Guadanucci, P., Wozniak, W., BocianSobkowska, J., Malendowicz, L.K. and Bornstein, S.R., 1997. 17 alpha-Hydroxylase and chromogranin A in 6th week human fetal adrenals. Horm Metab Res 29, 30-32. 
Ehrhart-Bornstein, M., Hinson, J.P., Bornstein, S.R., Scherbaum, W.A. and Vinson, G.P., 1998. Intraadrenal interactions in the regulation of adrenocortical steroidogenesis. Endocr Rev 19, 101-143.

Hammer, F., Subtil, S., Lux, P., Maser-Gluth, C., Stewart, P.M., Allolio, B. and Arlt, W., 2005. No evidence for hepatic conversion of dehydroepiandrosterone (DHEA) sulfate to DHEA: in vivo and in vitro studies. J Clin Endocrinol Metab 90, 3600-3605. li, M., Hoshiga, M., Negoro, N., Fukui, R., Nakakoji, T., Kohbayashi, E., Shibata, N., Furutama, D., Ishihara, T., Hanafusa, T., Losordo, D.W. and Ohsawa, N., 2009. Adrenal androgen dehydroepiandrosterone sulfate inhibits vascular remodeling following arterial injury. Atherosclerosis 206, 77-85.

Kim, Y., Seger, R., Suresh Babu, C.V., Hwang, S.Y. and Yoo, Y.S., 2004. A positive role of the PI3-K/Akt signaling pathway in PC12 cell differentiation. Mol Cells 18, 353359.

Krug, A.W., Grossmann, C., Schuster, C., Freudinger, R., Mildenberger, S., Govindan, M.V. and Gekle, M., 2003. Aldosterone stimulates epidermal growth factor receptor expression. J Biol Chem 278, 43060-43066.

Krug, A.W., Langbein, H., Ziegler, C.G., Bornstein, S.R., Eisenhofer, G. and EhrhartBornstein, M., 2009. Dehydroepiandrosterone-sulphate (DHEA-S) promotes neuroendocrine differentiation of chromaffin pheochromocytoma PC12 cells. Mol Cell Endocrinol 300, 126-131.

Liu, D. and Dillon, J.S., 2002. Dehydroepiandrosterone activates endothelial cell nitric-oxide synthase by a specific plasma membrane receptor coupled to Galpha(i2,3). J Biol Chem 277, 21379-21388.

Liu, D., O'Leary, B., Iruthayanathan, M., Love-Homan, L., Perez-Hernandez, N., Olivo, H.F. and Dillon, J.S., 2010. Evaluation of a novel photoactive and biotinylated dehydroepiandrosterone analog. Mol Cell Endocrinol, [Epub ahead of print].

Liu, S.L., Schmuck, S., Chorazcyzewski, J.Z., Gros, R. and Feldman, R.D., 2003. Aldosterone regulates vascular reactivity: short-term effects mediated by phosphatidylinositol 3-kinase-dependent nitric oxide synthase activation. Circulation 108, 2400-6.

Maninger, N., Wolkowitz, O.M., Reus, V.I., Epel, E.S. and Mellon, S.H., 2009. Neurobiological and neuropsychiatric effects of dehydroepiandrosterone (DHEA) and DHEA sulfate (DHEAS). Front Neuroendocrinol 30, 65-91.

Mesiano, S. and Jaffe, R.B., 1997. Developmental and functional biology of the primate fetal adrenal cortex. Endocr Rev 18, 378-403.

Radford, D.J., Wang, K., McNelis, J.C., Taylor, A.E., Hechenberger, G., Hofmann, J., Chahal, H., Arlt, W. and Lord, J.M., 2010. Dehdyroepiandrosterone sulfate directly 
activates protein kinase C-beta to increase human neutrophil superoxide generation. Mol Endocrinol 24, 813-821.

Rosenfeld, R.S., Rosenberg, B.J. and Hellman, L., 1975. Direct analysis of dehydroisoandrosterone in plasma. Steroids 25, 799-805.

Sicard, F., Ehrhart-Bornstein, M., Corbeil, D., Sperber, S., Krug, A.W., Ziegler, C.G., Rettori, V., McCann, S.M. and Bornstein, S.R., 2007. Age-dependent regulation of chromaffin cell proliferation by growth factors, dehydroepiandrosterone (DHEA), and DHEA sulfate. Proc Natl Acad Sci U S A 104, 2007-2012.

Sicard, F., Krug, A.W., Ziegler, C.G., Sperber, S., Ehrhart-Bornstein, M. and Bornstein, S.R., 2006. Role of DHEA and growth factors in chromaffin cell proliferation. Ann N Y Acad Sci 1073, 312-316.

Stanway, S.J., Delavault, P., Purohit, A., Woo, L.W., Thurieau, C., Potter, B.V. and Reed, M.J., 2007. Steroid sulfatase: a new target for the endocrine therapy of breast cancer. Oncologist 12, 370-374.

Vaudry, D., Stork, P.J., Lazarovici, P. and Eiden, L.E., 2002. Signaling pathways for PC12 cell differentiation: making the right connections. Science 296, 1648-1649.

Xiao, J., Zhou, Q. and Liu, Y., 2002. Variant PC12 cell line that spontaneously differentiates and extends neuritic processes. J Neurosci Res 69, 104-109.

Ziegler, C.G., Sicard, F., Lattke, P., Bornstein, S.R., Ehrhart-Bornstein, M. and Krug, A.W., 2008. Dehydroepiandrosterone Induces a Neuroendocrine Phenotype in Nerve Growth Factor-Stimulated Chromaffin Pheochromocytoma PC12 Cells. Endocrinology 149, 320-328.

Ziegler, C.G., Sicard, F., Sperber, S., Ehrhart-Bornstein, M., Bornstein, S.R. and Krug, A.W., 2006. DHEA reduces NGF-mediated cell survival in serum-deprived PC12 cells. Ann N Y Acad Sci 1073, 306-311.

\section{Legends to the figures}

Figure 1. RT-PCR demonstrates expression of steroid sulfatase mRNA in PC-12 cells. The PCR product has the expected length of $229 \mathrm{bp}$.

Figure 2. Neurite outgrowth of PC12 cells after $24 \mathrm{~h}$. (A) $20 \mathrm{ng} / \mathrm{ml}$ NGF induced neurite outgrowth, an effect significantly reduced by $10^{-6} \mathrm{~mol} / \mathrm{I}$ DHEAS and DHEA after $24 \mathrm{~h}$. DHEAS or DHEA alone did not influence neurite outgrowth. Addition of the blocker estrone sulfamate (EMATE) had no significant effect. (B-D) Representative bright field microscopy images 
demonstrate the reduction of NGF $(20 \mathrm{ng} / \mathrm{ml})$-induced neurite outgrowth by DHEA and DHEAS $\left(10^{-6} \mathrm{~mol} / \mathrm{l}\right)$, respectively in PC12 cells.

Figure 3. Expression of the neuronal marker protein SNAP-25. $20 \mathrm{ng} / \mathrm{ml}$ NGF significantly induced expression of SNAP-25, an effect significantly reduced by $10^{-6} \mathrm{~mol} / \mathrm{I}$ DHEAS and DHEA, respectively after 24h. DHEAS or DHEA alone did not influence SNAP-25 expression. The combinations with EMATE had the same effects as combinations without the blocker.

Figure 4. Expression of the neuroendocrine marker protein CGA. $10^{-6} \mathrm{~mol} / \mathrm{I}$ DHEAS and DHEA significantly induced the expression of CGA after $24 \mathrm{~h}$. NGF (20 $\mathrm{ng} / \mathrm{ml})$ alone had no effect on CGA expression but reduced DHEAS and DHEA induced CGA-expression. Combinations including EMATE had the same effects as combinations without the blocker.

Figure 5. DHEAS and DHEA significantly increased dopamine release of NGF-induced PC12 cells. NGF $(20 \mathrm{ng} / \mathrm{ml})$ alone lead only to a slight dopamine secretion compared to control cells. The effect on dopamine secretion was similar for DHEAS and DHEA. Combinations including EMATE had the same effects as combinations without the blocker.

Figure 6. DHEA and membrane-impermeable DHEA-BSA $\left(10^{-6} \mathrm{~mol} / \mathrm{l}\right)$ similarly affect NGF (20 ng/ml)-induced ERK1/2 phosphorylation after 5 min.

Figure 7. DHEA and DHEAS influence PC-12 cell differentiation towards an endocrine phenotype with increased dopamine secretion and chromogranin A expression. DHEA and DHEAS might mediate its effect via a fast non-genomic mechanism, docking initially at the plasma membrane. 
Figure

Figure 1: Ziegler et al. 
A

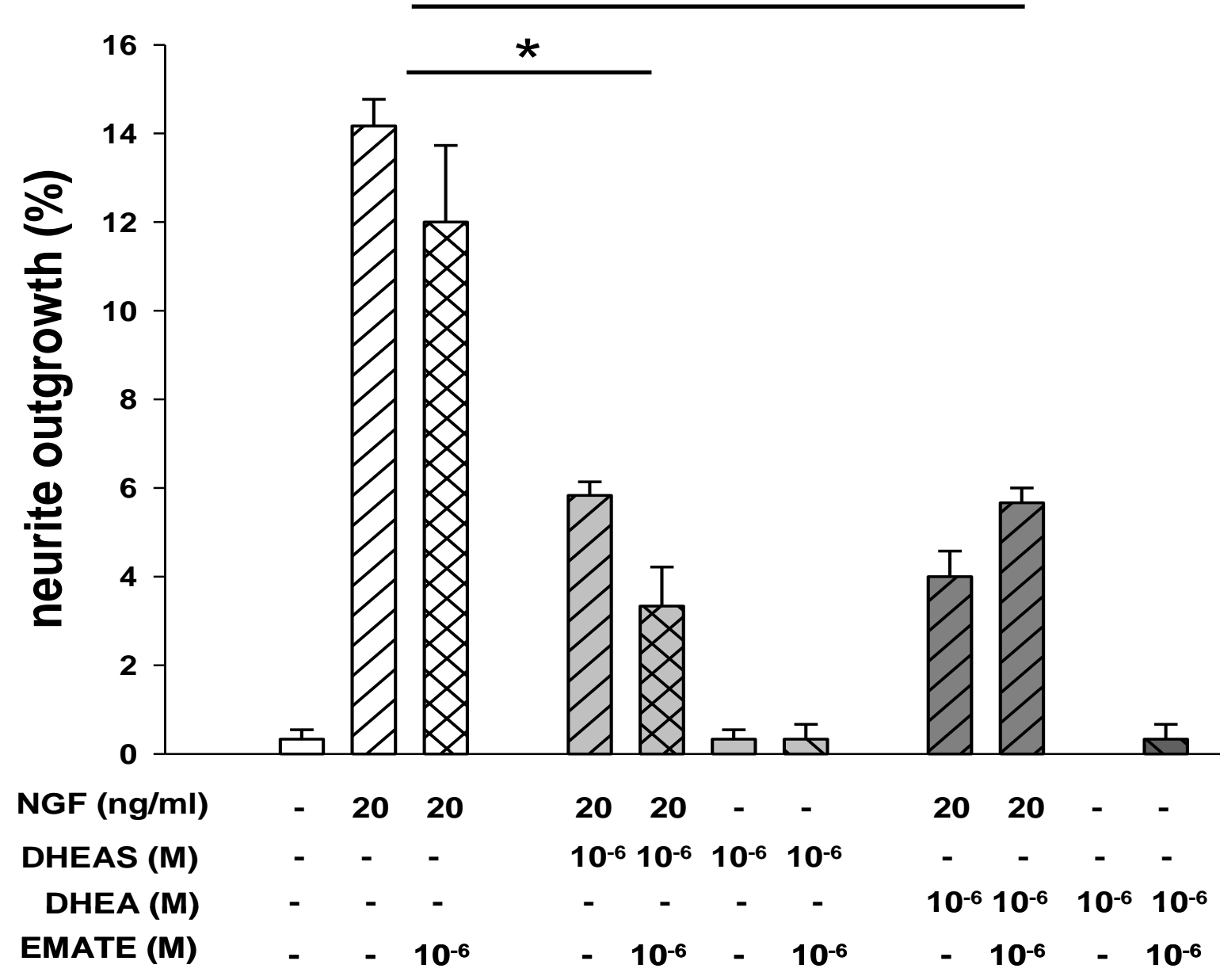

B

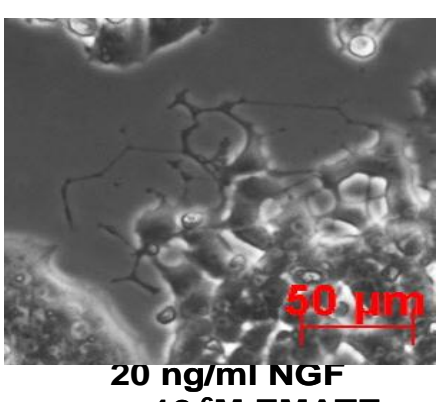

C

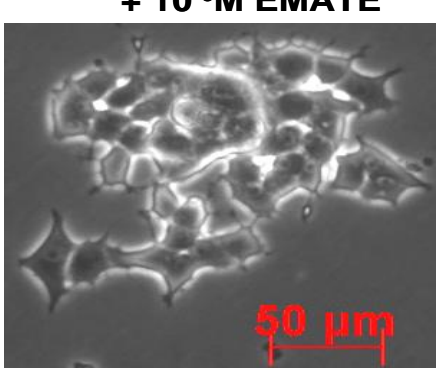

$20 \mathrm{ng} / \mathrm{ml}$ NGF

$+10^{-6} \mathrm{M}$ DHEA

$+10^{-6} \mathrm{M}$ EMATE

D

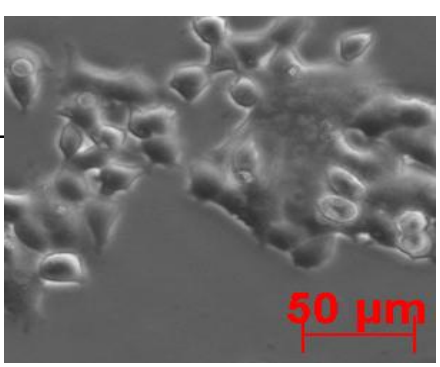

$20 \mathrm{ng} / \mathrm{ml} \mathrm{NGF}$

$+10^{-6} \mathrm{M}$ DHEA-S

$+10^{-6} \mathrm{M}$ EMATE

Figure 2: Ziegler et al. 


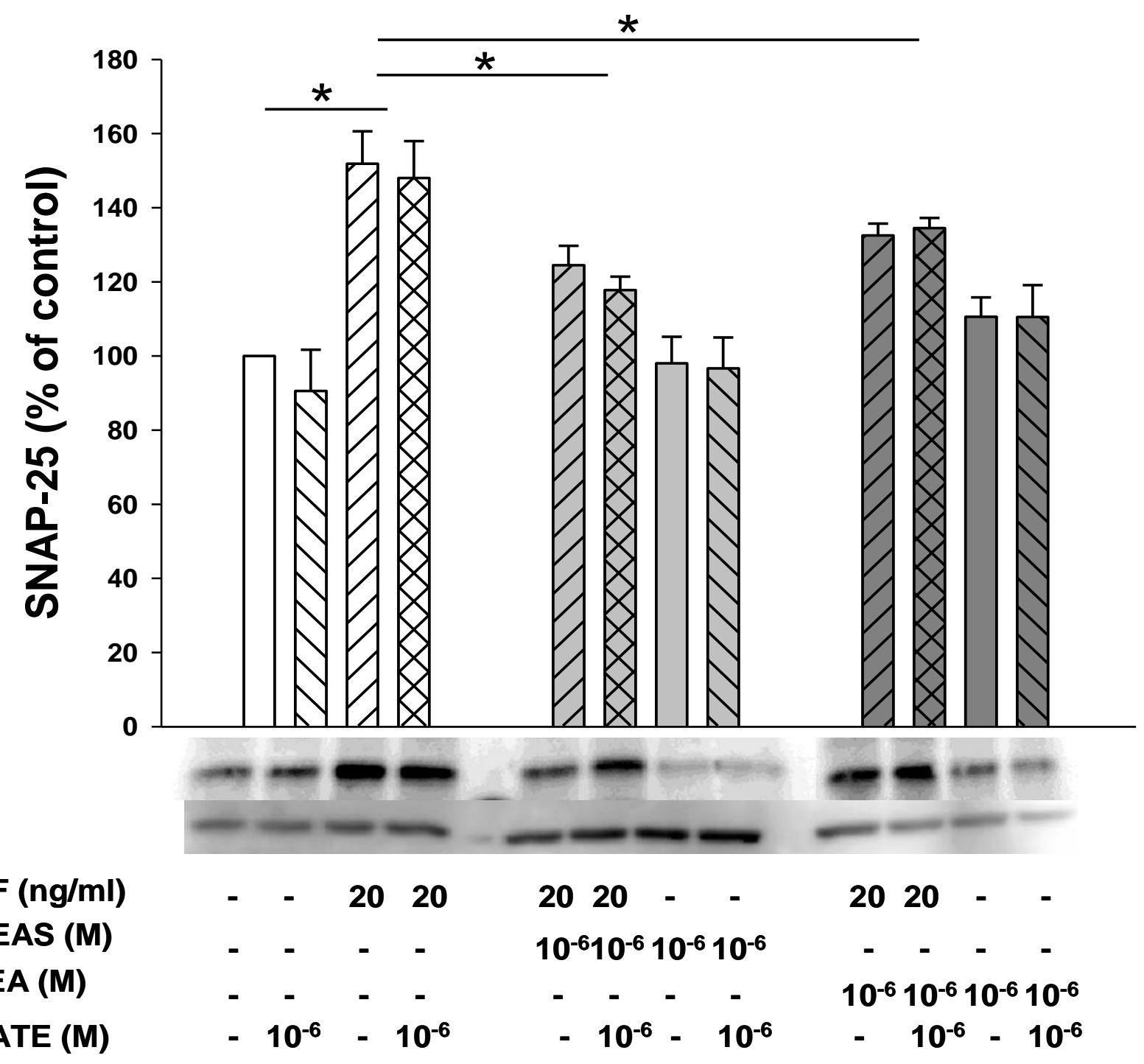

Figure 3: Ziegler et al. 


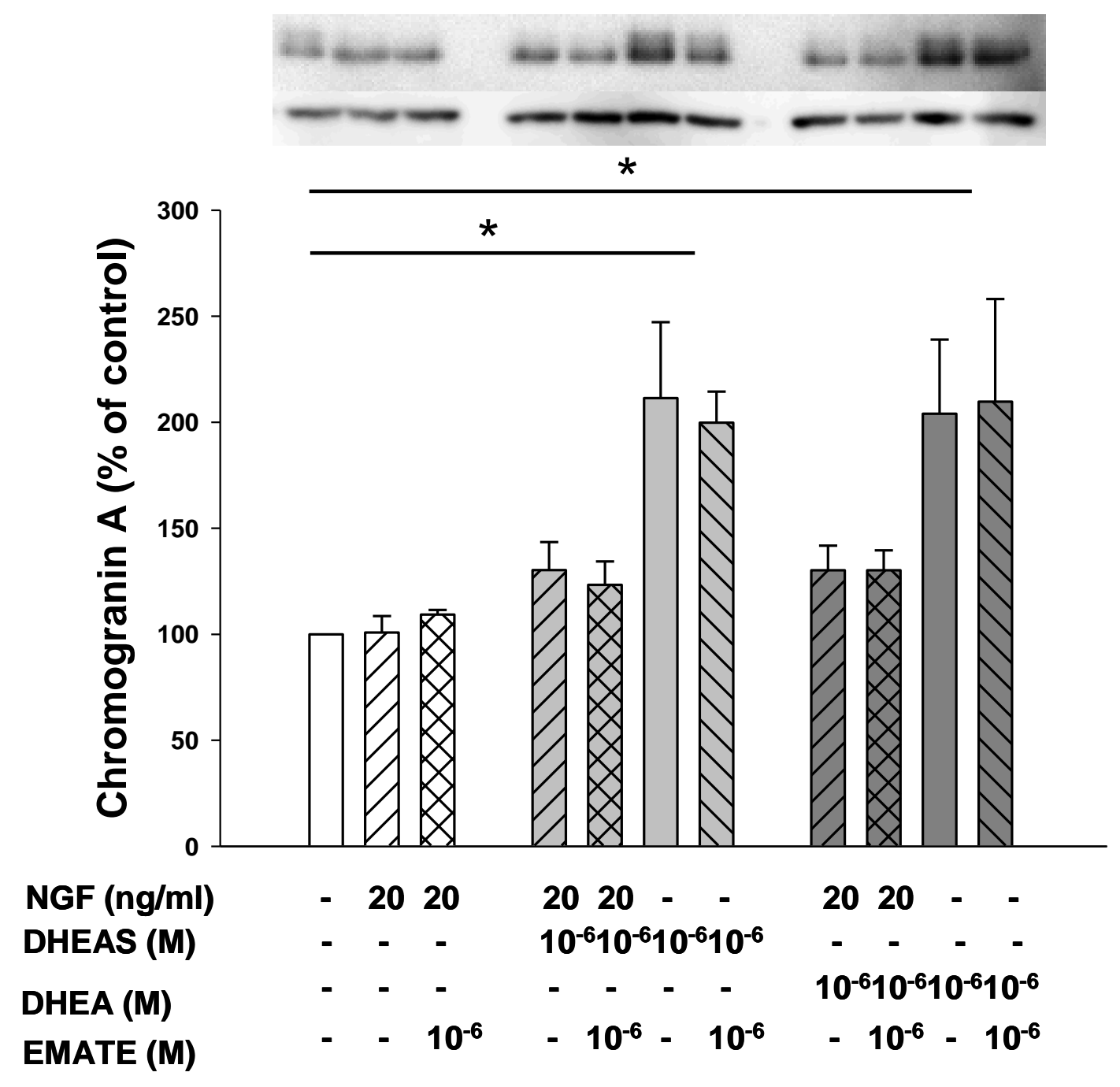

Figure 4: Ziegler et al. 


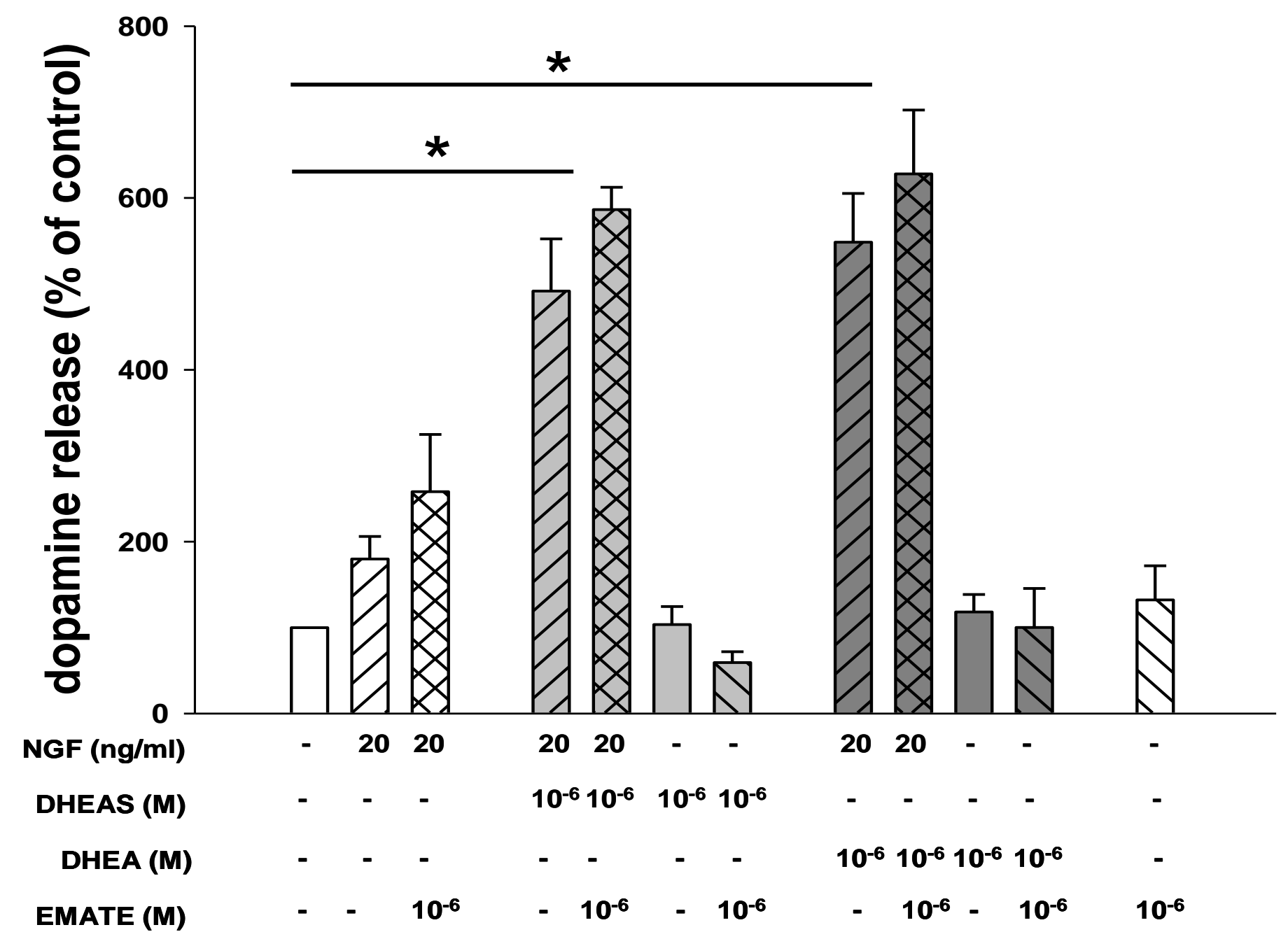

Figure 5: Ziegler et al. 


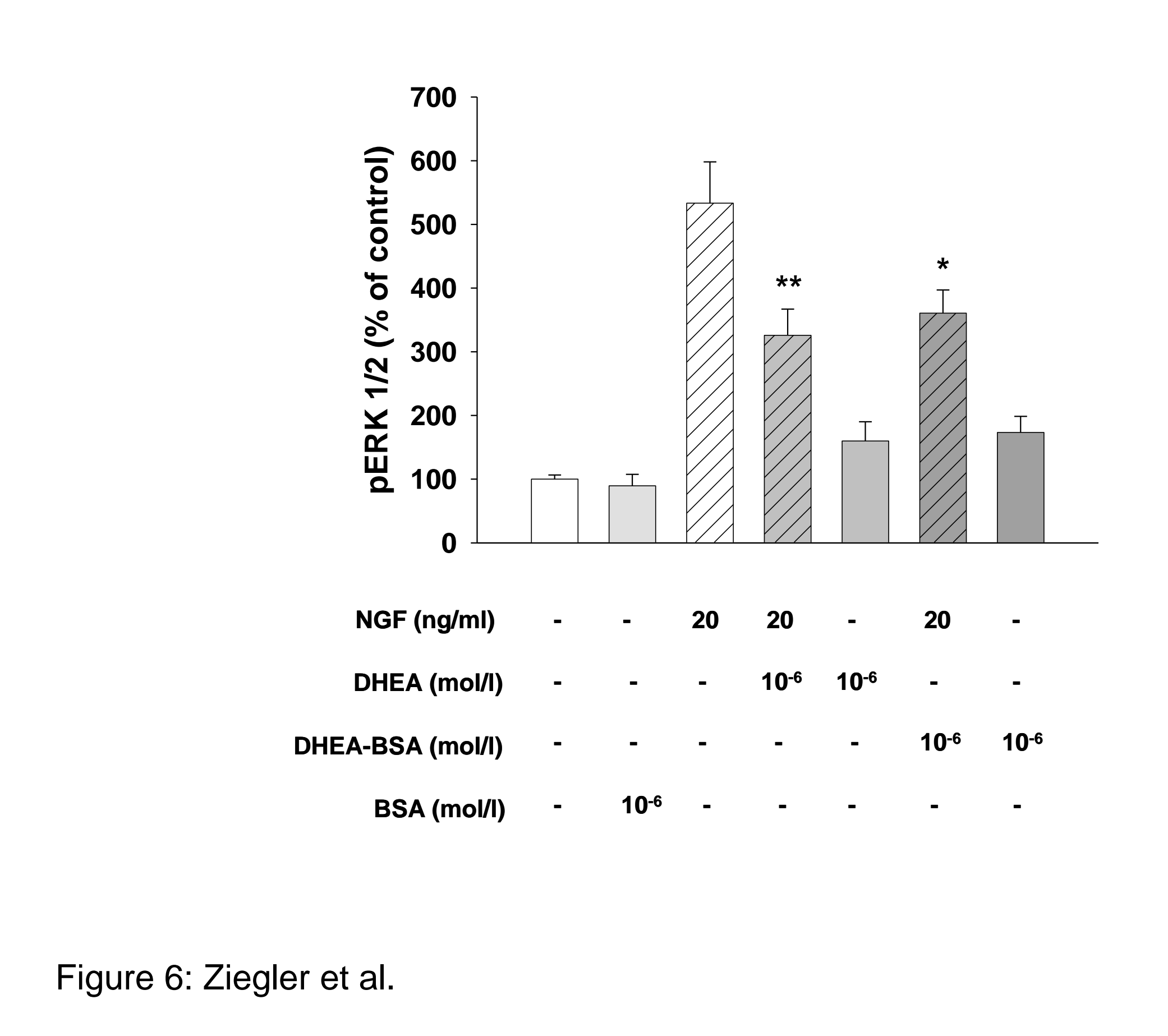




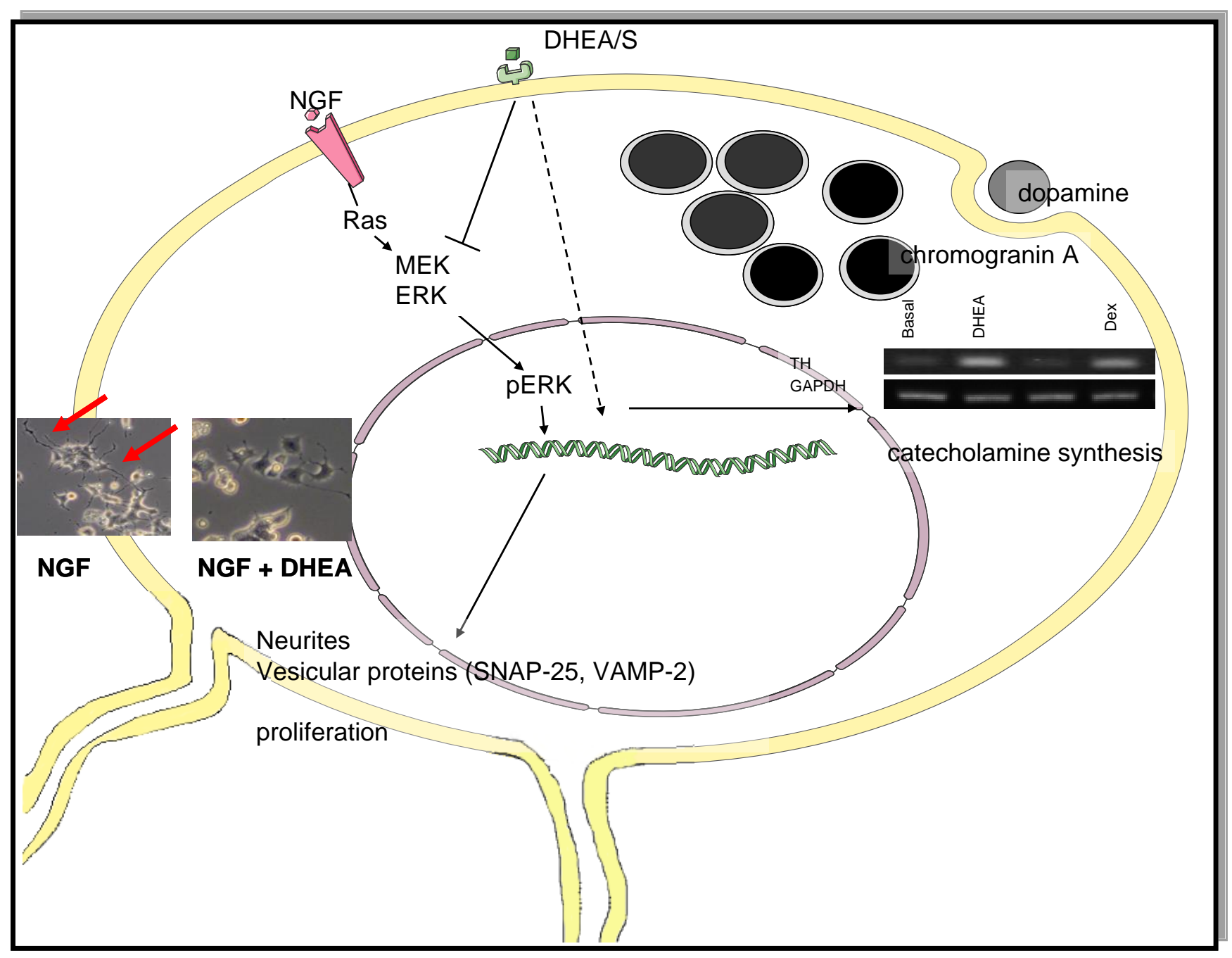

Figure 7: Ziegler et al. 